Jurnal Abdidas Volume 2 Nomor 5 Tahun 2021 Halaman 1217 - 1223

JURNAL ABDIDAS

http://abdidas.org/index.php/abdidas

\title{
Pelatihan Manajemen Pembelajaran Kewirausahaan dalam Meningkatkan Keterampilan Usaha bagi Mahasiswi yang Lulus Mata Kuliah Kewirausahaan
}

\author{
Eka Diana ${ }^{1}$, Fitriatun Wahyudi ${ }^{2}$, Eka Fani Rohmawati ${ }^{3}$, Rafika Laura Noviana $^{4}$, Nofi Ferandita ${ }^{5}$, \\ Nurul Azizah ${ }^{6}$, Musrifah ${ }^{7}$ \\ Universitas Nurul Jadid Paiton Probolinggo, Indonesia ${ }^{1,2,3,4,5,6,7}$ \\ E-mail: ekadianaalwi8@gmail.com
}

\begin{abstract}
Abstrak
Pembelajaran kewirausahaan di perguruan tinggi hendaknya menghasilkan lulusan yang siap berwirausaha. Akan tetapi dalam kenyataannya masih banyak mahasiswi sebagai calon lulusan perguruan tinggi tidak tertarik atau enggan berwirausaha. Hal ini dikarenakan beberapa persoalan yaitu kurangnya pengetahuan tentang kewirausahaan dan kurangnya motivasi kewirausahaan yang dapat mendorong berwirausahaan. Program pengabdian kepada masyarakat berupa pelatihan manajemen pembelajaran kewirausahaan dalam meningkatkan keterampilan usaha bertujuan memberikan pendidikan dan wawasan baru kepada mahasiswi tentang kewirausahaan serta memberikan motivasi agar dapat melakukan kewirausahaan. Metode pelaksanaan pengabdian ini menggunakan pelatihan dengan metode ceramah dan tanya jawab yang dilakukan secara luring. Pelaksanaan pengabdian ini pada akhirnya dapat memberikan dan menambah khasanah baru tentang kewirausahaan dan tertarik dalam melakukan wirausaha dengan kreatif dan inovatif.
\end{abstract}

Kata kunci: manajemen pembelajaran, kewirausahaan, keterampilan usaha

\begin{abstract}
Entrepreneurship in learning colleges produces graduates who are ready for entrepreneurship. However, in reality there are still many students as prospective college graduates who are not interested or reluctant to become entrepreneurs. This is due to several problems, namely lack of knowledge about entrepreneurship and lack of entrepreneurial motivation that can encourage entrepreneurship. The community service program in the form of entrepreneurial management training in improving business skills aims to provide education and new insights to female students about entrepreneurship and provide motivation to be able to do entrepreneurship. This service method uses training with lecture methods and questions and answers that are carried out in an attractive manner. The implementation of this service can ultimately provide and add new treasures about entrepreneurship and are interested in doing entrepreneurship creatively and innovatively. Keywords: learning management, entrepreneurship, business skills
\end{abstract}

Copyright (c) 2021 Eka Diana, Fitriatun Wahyudi, Eka Fani Rohmawati, Rafika Laura Noviana, Nofi Ferandita, Nurul Azizah, Musrifah

$\triangle$ Corresponding author

Address : Universitas Nurul Jadid Paiton Probolinggo

ISSN 2721-9224 (Media Cetak)

Email : ekadianaalwi8@gmail.com

DOI : https://doi.org/10.31004/abdidas.v2i5.450 
1218 Pelatihan Manajemen Pembelajaran Kewirausahaan dalam Meningkatkan Keterampilan Usaha bagi Mahasiswi yang Lulus Mata Kuliah Kewirausahaan - Eka Diana, Fitriatun Wahyudi, Eka Fani Rohmawati, Rafika Laura Noviana, Nofi Ferandita, Nurul Azizah, Musrifah

DOI: https://doi.org/10.31004/abdidas.v2i5.450

\section{PENDAHULUAN}

Perguruan tinggi mempunyai peran dalam mempersiapkan wirausaha. Dimana hakikat persiapan kader wirausaha ialah dalam segi penempatan karakter wirausaha. Dengan kata lain persiapan manusia wirausaha terdapat pada sumber daya kekuatan pribadi manusia untuk menjadikan dinamis serta kreatif selain mampu berusaha untuk hidup serta berprestasi sebagai ciri-ciri dari seorang wirausaha (Siri, Buhaerah, \& Arafah, 2014). Lebih lanjut, pemberdayaan masyarakat menjadi salah satu tugas penting pemerintah melalui lembaga pendidikan tinggi. Pemberdayaan merupakan sebuah konsep ekonomi yang mengandung nilai-nilai sosial. Menurut Chamber dalam Rumawas (2019) konsep pemberdayaan mencerminkan paradigma baru pembangunan yang bersifat berpusat pada masyarakat (people centered), partisipatif (participatory), memberdayakan (empowering) dan berkelanjutan (sustainable).

Berbagai krisis yang melanda bangsa Indonesia merupakan suatu keharusan bagi rakyat Indonesia untuk mempersiapkan diri dalam menghadapi future challenges. Dimana persiapan yang dilakukan tersebut sangat bersentuhan dengan bagaimana sumber daya manusia yang ada dapat ditingkatkan dengan memberikan berbagai keterampilan hidup (life skill) serta menambah wawasan kewirausahaan. Menjadi seorang wirausahawan yang terdidik serta terlatih menghadapi segala tantangan dan mampu mencari peluang usaha merupakan suatu alternatif yang sangat menguntungkan bagi para mahasiswa untuk diterapkan dalam kehidupan nyata (Poltera, 2017)

Mahasiswa sebagai agen perubahan maka perlu dibimbing dan dilatih untuk menjadi seorang wirausahawan yang handal yang dapat menciptakan lapangan pekerjaan baru bagi masyarakat. Oleh sebab itu pemberdayaan sangat penting mengingat tujuan pemberdayaan menurut Somodiningrat dalam (Rumawas, 2019), yaitu 1) meningkatkan pendapatan masyarakat ditingkat bawah serta menurunnya jumlah kemiskinan, 2) berkembangknya kapasitas masyarakat dalam meningkatkan kegiatan sosial ekonomi produktif, 3) berkembangnya kemampuan masyarakat serta meningkatnya kapasitas kelembagaan masyarakat. Pengelolaan pembelajaran kewirausahaan di perguruan tinggi sangat penting mengingat output yang dihasilkan akan memberikan warna baru dalam kehidupan masyarakat. Oleh karenanya pengelolaan pembelajaran kewirausahan yang tepat akan menghasilkan outcome yang mempunyai jiwajiwa wirausaha.

Hal ini tentunya sejalan dengan hasil penelitian yang dilakukan oleh Akola dan Heinonen dalam (Christanti, 2016) yang mana penelitian tersebut menghasilkan bahwa ketika sistem pendidikan dan pelatihan menggabungkan kreativitas serta kompetensi manajerial kewirausahaan dalam metodologi pengajaran maka polapikir serta keterampilan terikat lebih erat dengan seni kewirausahaan. Dengan kata lain terdapat peranan dari pendidikan dan pelatihan kewirausahaan dalam menumbuhkan semangat kewirausahaan. Akan tetapi dalam realitanya masih banyak mahasiswi yang enggan terdorong untuk meningkatkan keterampilan kewirausahaan serta semangat kewirausahaan sekalipun mereka telah lulus menempuh mata kuliah kewirausahaan. 
1219 Pelatihan Manajemen Pembelajaran Kewirausahaan dalam Meningkatkan Keterampilan Usaha bagi Mahasiswi yang Lulus Mata Kuliah Kewirausahaan - Eka Diana, Fitriatun Wahyudi, Eka Fani Rohmawati, Rafika Laura Noviana, Nofi Ferandita, Nurul Azizah, Musrifah

DOI: https://doi.org/10.31004/abdidas.v2i5.450

Berdasarkan survei yang dilakukan terdapat dua permasalahan yang dapat diidentifikasikan sebagai dasar di dalam pelaksanaan kegiatan PKM oleh tim pengabdi. Kedua masalah tersebut adalah 1) kurangnya pemahaman tentang kewirausahaan, 2) kurangnya motivasi dalam wirausaha.

Berdasarkan pertimbangan tersebut di atas dan survei awal terhadap mitra, maka perlu diselenggarakan pelatihan manajemen pembelajaran kewirausahaan dalam meningkatkan keterampilan usaha bagi mahasiswi yang lulus mata kuliah kewirausahaan.

\section{METODE}

Kegiatan pengabdian dilaksanakan kepada mahasiswi yang telah lulus mata kuliah kewirausahaan dengan dilaksanakan melalui luring atau offline. Pelaksanaan pengabdian ini menggunakan metode ceramah dan tanya jawab. Tim pengabdi dalam kegiatan ini terdiri dari satu dosen dan 6 mahasiswi (kolaborasi dosen dan mahasiswi) dari program studi Prodi Manajemen Pendidikan Islam Universitas Nurul Jadid Paiton Probolinggo. Adapun peserta yang mengikuti kegiatan pelatihan ini adalah sebagian kecil atau mengambil sampel mahasiswa Manajemen Pendidikan Islam yang telah lulus mata kuliah kewirausahaan sekitar 7 mahasiswi dari jumlah keseluruhan mahasiswa dengan didasarkan pertimbangan karena masih masa pandemi Covid 19. Terdapat tiga tahapan dalam kegiatan yang dilakukan terdiri dari tahap persiapan, tahap pelaksanaan dan tahap evaluasi. Ketiga tahap tersebut secara detail sebagai berikut:

\section{Tahap Persiapan}

Kegiatan yang dilakukan pada tahap persiapan ini, pengabdi melakukan observasi terhadap kebutuhan mitra serta menentukan topik pelatihan yang akan dilakukan. Observasi awal dilakukan dalam rangka mengetahui kebutuhan mitra yang berkaitan dengan kewirausahaan. Observasi awal diperlukan dalam rangka menentukan kegiatan pengabdian yang akan dilakukan terkait materi yang akan diberikan kepada peserta pelatihan manajemen kewirausahan. Selain itu tahap persiapan dilakukan untuk melakukan koordinasi dengan peserta pelatihan untuk menentukan hari, tanggal, dan jam pelaksaan pelatihan. Selain itu tahap ini bertujuan untuk menyiapkan materi yang sesuai dengan topik pelatihan yang telah ditentukan serta melakukan persiapan presentasi yang akan diberikan kepada peserta pelatihan dengan menggunakan metode yang sesuai dengan situasi dan kondisi pelaksanaan pelatihan.

2. Tahap Pelaksanaan

Tahap pelaksaaan kegiatan pelatihan dilaksanakan pada hari Sabtu 31 Juli 2021 dengan sistem luring yang bertempat di asrama putri pondok pesantren Nurul Jadid.

3. Tahap Evaluasi

Tahap evaluasi dilaksanakan dalam rangka melihat kembali rangkaian proses pelaksanaan pelatihan mulai dari awal kegiatan sampai dengan hasil pelatihan. Selain itu, evaluasi dari pelaksanaan pelatihan diperoleh dari masukan dan pendapat peserta pelatihan yang waktu pelaksanaan diberikan kesempatan untuk mengemukakan pendapat dan sarannya terkait pelatihan manajemen pembelajaran 
1220 Pelatihan Manajemen Pembelajaran Kewirausahaan dalam Meningkatkan Keterampilan Usaha bagi Mahasiswi yang Lulus Mata Kuliah Kewirausahaan - Eka Diana, Fitriatun Wahyudi, Eka Fani Rohmawati, Rafika Laura Noviana, Nofi Ferandita, Nurul Azizah, Musrifah

DOI: https://doi.org/10.31004/abdidas.v2i5.450

kewirausahaan.

\section{HASIL DAN PEMBAHASAN}

Pelatihan manajemen pembelajaran kewirausahaan ini diikuti oleh mahasiswi prodi Manajemen Pendidikan Islam yang telah lulus mata kuliah kewirausahaan sebanyak 6 orang. Pada waktu pelaksaaan pelatihan ini mahasiswi yang terlibat menyimak dengan seksama dan juga antusias mendengarkan paparan yang disampaikan oleh pemateri. Lebih lanjut, para peserta juga antusias dalam tanya jawab yang diberikan setelah materi selesai dipaparkan oleh penyaji terkait dengan manajemen pembelajaran kewirausahaan. Lebih jelasnya terkait dengan pelaksanaan pelatihan tersebut dapat dilihat pada gambar di bawah ini.

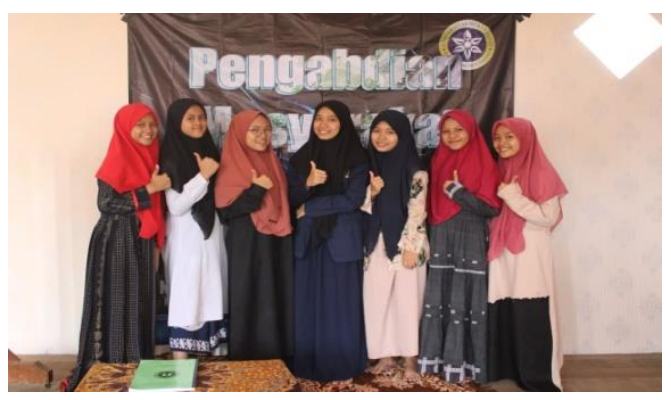

Gambar 1. Peserta Pelatihan

Materi yang disampaikan adalah mengenai manajemen pembelajaran kewirausahan yang dalam hal ini berisikan tentang bagaimana mengelolaan pembelajaran kewirausahan yang membekali para peserta pelatihan dengan lifeskills untuk menjadi wirausahawan. Pada kesempatan ini materi mengupas mengenai pengelolaan pembelajaran kewirausahaan mulai dari tahap perencanaan sampai dengan tahap evaluasi. Tujuan dalam pemaparan materi ini adalah untuk memberikan pengetahuan dalam pengelolaan pembelajaran kewirausahan agar peserta pelatihan mengetahui mengenai kewirausahan sehingga mendorong peserta pelatihan menjadi insan wirausahan yang mandiri. Pembahasan materi ini dapat dilihat pada gambar di bawah ini.

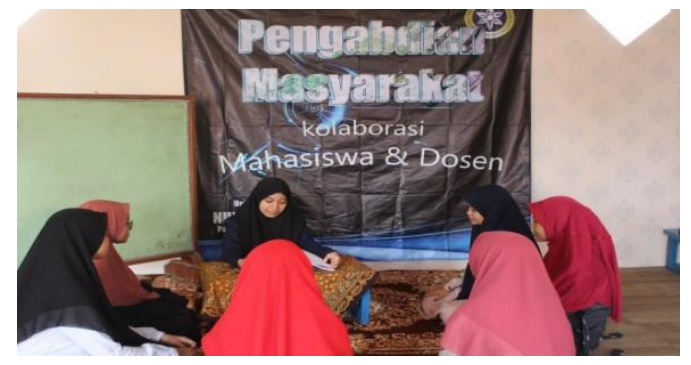

Gambar 2. Penjelasan Materi Pelatihan

Pemaparan dilanjutkan dengan materi kedua yaitu terkait motivasi dalam kewirausahaan. Pemaparan materi ini berisikan motiv dalam berwirausaha sehingga dapat memberikan daya kejut kepada peserta pelatihan agar meningkatkan jiwa kewirausahaan. Pemaparan motivasi kewirausahan berisikan dimensi dan faktor-faktor motivasi kewirausahan itu sendiri. Pembahasan materi ini dapat dilihat pada gambar di bawah ini.

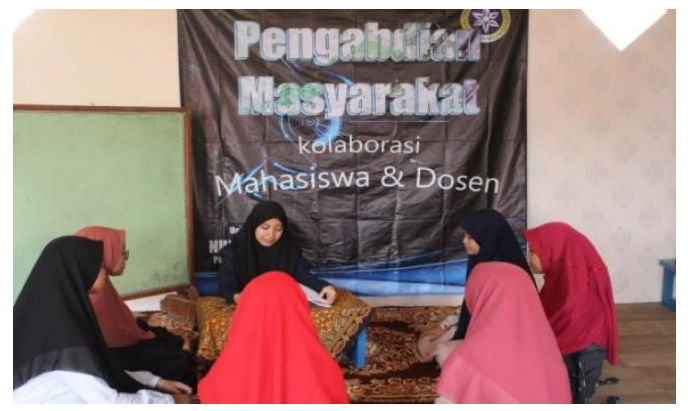

Gambar 3. Penjelasan Materi Pelatihan

Keberadaan pembelajaran kewirausahaan sangat penting bagi mahasiswa sebagai outcome 
1221 Pelatihan Manajemen Pembelajaran Kewirausahaan dalam Meningkatkan Keterampilan Usaha bagi Mahasiswi yang Lulus Mata Kuliah Kewirausahaan - Eka Diana, Fitriatun Wahyudi, Eka Fani Rohmawati, Rafika Laura Noviana, Nofi Ferandita, Nurul Azizah, Musrifah

DOI: https://doi.org/10.31004/abdidas.v2i5.450

dari pendidikan tinggi serta agen perubahan dalam masyarakat. Dimana konsep kewirausahaan terdiri dari aspek utama yakni berorientasi pada nilai (value oriented) serta berorientasi pada tujuan (value oriented). Selain itu salah satu muatan yang terpenting dalam memperkenalkan kewirausahaan kepada mahasiswa adalah internalisasi value system yang terdapat dalam kewirausahaan yaitu kemandirian, berpikir kreatif, soft skill, keterampilan interpersonal, dll (Muhtarom, Nizaruddin, \& Zuhri, 2017). Dampak jangka panjang dalam yang diharapkan dalam internalisasi tersebut adalah kemampuan peluang yang dapat menghasilkan nilai lebih dan memberikan kebermanfaatan bagi orang lain. Oleh sebab itu, untuk dapat menjadi seorang wirausahawan mahasiswa perlu diberikan pelatihan yang baik guna mendorong mahasiswa mempunyai jiwa-jiwa kewirausahaan serta meningkatkan keterampilan usaha dalam dirinya.

Pelatihan dalam pandangan Barry Chusway dalam (Marganingsih \& Pelipa, 2017) merupakan proses mengajarkan keahlian dan memberikan knowledge serta sikap supaya mereka dapat melakukan tanggung jawabnya sesuai dengan standar. Adanya pelatihan menjamin ketersedianya sumber daya manusia yang memiliki keahlian serta mempergunakan pikirannya secara kritis. Oleh karena itu pelatihan kewirausahaan sangat penting guna memberikan pengetahuan serta keterampilan kepada mahasiswa (Muhtarom et al., 2017). Pelatihan manajemen pembelajaran kewirausahaan dalam meningkatkan keterampilan usaha bagi mahasiswi dilakukan berdasarkan hal tersebut.

Materi pertama mengenai pengelolaan pembelajaran kewirausahaan. Pembelajaran kewirausahan menurut Rae dan Carswell dalam (Purnomo, 2015) merupakan suatu proses pemecahan masalah yang berorientasi pada penyimpanan serta penggunaan pengetahuan kewirausahaan dalam jangka panjang. Dalam hal ini pembelajaran kewirausahaan disederhanakan sebagai belajar bagaimana mengenali kesempatan. Sejalan dengan itu menurut Ade Suyitno (2013) pembelajaran kewirausahaan ialah usaha terencana serta aplikatif guna meningkatkan knowledge, niat dan kemampuan peserta didik dalam mengembangkan potensinya yang diwujudkan dalam perilaku kreatif, inovatif serta berani mengelola resiko. Pembelajaran kewirausahaan sebagai life sklills bagi mahasiswa tidak boleh ditinggalkan yang terdiri dari beberapa prinsip dalam menjalankan pembelajaran kewirausahaan yaitu: belajar untuk mengetahui kewirausahaan (learning to know), belajar untuk melakukan kegiatan wirausaha (learning to do), belajar untuk mempraktikkan kegiatan wirausaha (learning to be), dan belajar bersama yang lain dalam interaksi sosial dalam berwirausaha (learning to live together) (Nuryanti S, 2016).

Peserta pelatihan dengan mengetahui pengelolaan pembelajaran kewirausahaan yang dimulai dari perencanaan kewirausahaan sampai evaluasi kewirausahan dapat menumbuhkan jiwa kewirausahan dalam diri peserta pelatihan yang nantinya akan tergerak untuk menjadi wirausahawan dan wirausahawati. Selain itu para peserta pelatihan sangat antusias dalam mendengarkan penjelasan pemateri terkait dengan materi manajemen pembelajaran kewirausahaan tersebut meskipun dalam pelaksanaannya 
1222 Pelatihan Manajemen Pembelajaran Kewirausahaan dalam Meningkatkan Keterampilan Usaha bagi Mahasiswi yang Lulus Mata Kuliah Kewirausahaan - Eka Diana, Fitriatun Wahyudi, Eka Fani Rohmawati, Rafika Laura Noviana, Nofi Ferandita, Nurul Azizah, Musrifah

DOI: https://doi.org/10.31004/abdidas.v2i5.450

menggunakan metode ceramah sebagai metode utama karena keterbatasan media yang ada di tempat pelaksanaan pelatihan.

Selain itu, para peserta pelatihan memberikan apresiasi terhadap apa yang telah disampaikan penyaji terkait pembelajaran kewirausahaan ini, hal ini ditunjukkan dengan terdapatnya diskusi bersama antara penyaji dengan peserta pelatihan sehingga memberikan mindset baru kepada peserta pelatihan pembelajaran kewirausahan tersebut.

Materi kedua yang diberikan merupakan motivasi kewirausahaan. Motivasi merupakan pendorong atau daya gerak seseorang melakukan sesuatu. Dengan redaksi yang berbeda motivasi kewirausahaan menurut Ratnawati dan Kuswardi (2010) merupakan kondisi yang mendorong, menggerakkan serta mengarahkan keingian seseorang untuk melaksanakan kewirausahaan dengan cara mandiri, percaya diri, berani mengabil resiko serta kreatif serta inovatif.

Selain itu dalam pandangan Venesaar (2006) motivasi seseorang menjadi wirausaha terbagi dalam tiga dimensi, yaitu: ambisi kemandirian (ambition for freedom), realisasi diri (self realiasation), serta faktor pendorong (pushing factors). Dengan redaksi yang berbeda akan tetapi maksudnya sama, menurut Saiman dalam (Edwar, 2016) terdapat beberapa motif yang memotivasi individu berwirausaha diantaranya adalah a) memperoleh penghasilan, b) memperoleh kebebasan, c) kemandirian, d) memperoleh keuntungan/laba, e) impian personal, f) menciptakan kerja, g) mengatasi pengangguran, h) pemanfaatan sumber daya yang tersedia, i) adanya modal, j) karena kreatif dan inovatif, k) memiliki mentalitas wirausahaawan, 1) ingin mewujudkan mimpi sebagai wirausahawan, m) karena ingin berbuat kebaikan, berbuat sosial bagi orang lain.

Dalam menyampaikan materi kedua ini, pemateri memberikan motivasi kepada para peserta pelatihan agar senantiasa dapat mencari peluang untuk melakukan kewirausahaan sehingga nantinya sesuai dengan apa yang menjadi motif peserta pelatihan untuk berwirausaha. Dalam pelaksanaan materi motivasi ini para peserta sangat antusias mendengarkan paparan demi paparan penyaji. Setelah selesai menyampaikan materi terkait motivasi kewirausahaan pemateri memberikan beberapa kesempatan kepada peserta pelatihan untuk bertanya. Kemudian pemateri bertanya kepada peserta pelatihan terkait motivnya menjadi wirausahawan. Dalam pelaksanaan kegiatan ini para peserta pelatihan sangat senang dan bersemangat berwirausaha.

Dampak dari pelaksanaan pelatihan ini adalah para peserta pelatihan mengetahui serta memahami tentang kewirausahaan sehingga dalam diri peserta pelatihan timbul jiwa-jiwa kewirausahaan yang dapat mendorong peserta pelatihan menjadi seorang wirausahawan yang handal yang dapat memberikan kebermanfaatan kepada masyarakat.

\section{SIMPULAN}

Pelaksanaan pengabdian kepada masyarakat ini merupakan wujud nyata dalam memberikan pemahaan terkait kewirausahaan serta memberikan dorongan bagi mahasiswa untuk berwirausaha. Dengan adanya pelatihan ini mahasiswi yang menjadi peserta pelatihan dapat pengalaman tambahan tentang pengetahuan dibidang wirausaha, 
1223 Pelatihan Manajemen Pembelajaran Kewirausahaan dalam Meningkatkan Keterampilan Usaha bagi Mahasiswi yang Lulus Mata Kuliah Kewirausahaan - Eka Diana, Fitriatun Wahyudi, Eka Fani Rohmawati, Rafika Laura Noviana, Nofi Ferandita, Nurul Azizah, Musrifah

DOI: https://doi.org/10.31004/abdidas.v2i5.450

merubah mindset terhadap kewirausahaan, serta terpacu untuk melakukan kewirausahan yang memberikan dampak bagi dirinya dan masyarakat. Sebagai harapan untuk kedepannya, pelatihan sejenis dapat dilakukan dan dikembangkan sesuai dengan kebutuhan dilapangan.

\section{DAFTAR PUSTAKA}

Christanti, A. (2016). Studi Peranan Pelatihan Kewirausahaan Terhadap Pembentukan Sikap Dan Intensi Kewirausahaan Di Sentra Industri Produk Roti Dan Kue Rungkut Lor, Surabaya. Agora, 4(1), 242-248. Retrieved From Http://Publication.Petra.Ac.Id/Index.Php/Manaj emen-Bisnis/Article/View/4249

Edwar, M. (2016). Motivasi Berwirausaha. Jurnal Media Wahana Ekonomika, 13(1), 90-98.

Marganingsih, A., \& Pelipa, E. D. (2017). Pengaruh Pelatihan Keterampilan Berwirausaha Terhadap Hasil Belajar Mahasiswa. Vox Edukasi, 8(2).

Muhtarom, M., Nizaruddin, N., \& Zuhri, M. S. (2017). Pelatihan Kewirausahaan Di Universitas Pgri Semarang. E-Dimas, 8(1), 104. Https://Doi.Org/10.26877/E-Dimas.V8i1.1379

Nuryanti S, B. L. (2016). Manajemen Pembelajaran Kewirausahaan Melalui Pendekatan Experiental Learning Di FPEB Universitas Pendidikan Indonesia. Manajerial, 15(1), 7086.

Poltera. (2017). Pelatihan Kewirausahaan Masiswa Merubah Mainset Pekerja Menjadi Wirausaha. Retrieved From Http://Www.Poltera.Ac.Id/Pelatihan-

Kewirausahaan-Mahasiswa-Merubah-MindsetPekerja-Menjadi-Wirausaha/.

Purnomo, M. (2015). Dinamika Pendidikan Kewirausahaan: Pemetaan Sistematis Terhadap Pendidikan, Pengajaran, Dan Pembelajaran. Jurnal Dinamika Manajemen, 6(1), 79-120.

Rumawas, W. (2019). Pelatihan Kewirausahaan Wanita Kaum Ibu Dan Pemuda Remaja Putri Jemaat Bukit Moria Malalayang. Jurnal Lppm Bidang Ekososbudkum, 4(2000), 52-58. Retrieved From Https://Ejournal.Unsrat.Ac.Id/Index.Php/Lppm
ekososbudkum/Article/View/24117

Siri, M., Buhaerah, B., \& Arafah, A. (2014). Ibkpengembangan Kewirausahaan Bagi Mahasiswa Dan Alumni Di Universitas Muhammadiyah Parepare. 2, 611-620.

Suyitno, A. (2013). Pendidikan Kewirausahaan Teori Dan Praktek. Jakarta: Enterpreneurship Edupaper. 